two women which, owing to the foresight of the late Prof. Struthers and of Prof. Reid, have been slowly accumulated and safely preserved in the anatomical museum of the university. These prehistoric Aberdonians were of low stature ( 5 feet 2 inches to 5 feet 4 inches), with rounded heads which measured in breadth from 82 per cent. to 85 per cent. of their length. One can see, by referring to "An Analysis of Anthropometric Statistics," a contribution made to this volume of the Proceedings by Mr. John Gray, that only about 12 per cent. of the present inhabitants of Aberdeenshire possess heads which, in the proportion of their diameters, resemble those of the prehistoric race. Further, it is evident that the present inhabitants of Aberdeenshire stand, as regards the diameter of the head-the only racial characteristic that can be dealt with-in an intermediate position between the long-headed highlanders of the west of Scotland and the short-headed prehistoric people of the east coast. The natural inference appears to be that the present race of the north-east of Scotland is the result of a fusion of the east and west types-but the west has exerted the stronger influence. One of the two female skulls described by Dr. Low is that of a woman who, in shape of head, belonged to the west rather than to the east type. She may have been an exceptional member of the " shortcyst " race, but it is more probable that she was a western woman captured by the eastern invaders. Those who seek to discover the factors which determine the shape of the head will find most valuable material in the fourteen plates contributed by Prof. Reid. They represent serial sections of the heads of two subjects which had been very successfully prepared.

In these Proceedings one can recognise the influence that the Anatomical Society exerts on the medical graduates of Aberdeen. A skeleton of a Chinese coolie sent from Singapore, a Boxer's skull brought from north China, five Wa Kamba skulls and ten Wasoga crania collected in Uganda, provide material for the junior members to examine and report on. A paper contributed by Dr. F. W. Moir contains the results of a prolonged study of the people of Ashanti. Is it not strange that the University of London, in the very centre of the Empire, offers no such stimulus to its medical graduates as is given in Aberdeen? When the board of studies for human anatomy and morphology was recently constituted in the University of London the study of human races was, for all practical purposes, completely excluded.

The eyesight of the people in the north-east of Scotland is remarkably good. Drs. Usher and Stoddart found, from the examination of 400 students, that 15 per cent. were myopic or short sighted; Fuchs found in Germany that 60 per cent. of students at a corresponding age were myopic ; Norris and Oliver give 28 per cent. as the corresponding figure for American students. About three in every hundred of the Aberdeen school children are myopic; the proportion in Edinburgh is almost twice that number. Seven per cent. of the Aberdeen police are short-sighted.

In conclusion, it is to be hoped that the oblivion which so frequently overtakes the Proceedings of local societies, because of their inaccessibility to other workers, will spare the Proceedings of which this volume is but one of a series.

\section{HYDROLOGY IN THE UNITED STATES.}

THE Geological Survey Department of the United States embraces much wider duties than those covered by the similar department in this country, and the following notes upon some of the various matters with which it deals, and of the trouble taken to afford information as to the mineral resources and water supply of America, may be of interest.

The United States Geological Survey Department was created by an Act of Congress in 1879 . From time to time its duties, as originally set out, have been considerably extended. For administrative purposes the survey is now divided into branches and divisions, comprising geology, topography, hydrography, with offices charged with administration and the publication of maps and reports.

The department of the Geological Survey has charge and classification of all public lands; the examination of the geological structure, mineral resources, and the products of the national domains; the survey of forest reserves and the preparation of topographic and geologic maps. The hydrographic and hydrological branch has charge of all investigations relating to the occurrence of water as a mineral and as a source of wealth to the country. It is engaged in making systematic measurements of the rivers and streams throughout the States, and of the flow of water and the supply available, whether for domestic use or as a source of power. It also, through the Reclamation Service, prepares plans for the construction of reservoirs, canals, and other works for the irrigation of arid lands, of which there are very large areas in America, and superintends the carrying out of works that have been decided on for reclamation.

To show the thorough way in which the work of the department is carried out and the pains taken to ensure efficiency, recently a conference was called by the chief engineer for the purpose of enabling the heads of the engineering staff of the Reclamation. Service (twenty-five in number) to become acquainted with their work, and of exchanging views and information as to the works in hand and those planned for the future, and so secure uniformity of method in carrying out their work. At this conference an address was given by the chief engineer on the duties of the officers engaged in the work, and papers were read by the engineers having charge of the various works in execution. A record of these proceedings, with copies of the papers and other information, is given in one of the State papers issued by the department. ${ }^{2}$

Nearly two hundred engineers, hydrographers, and topographers are in the employ of the Reclamation Department alone, and comprehensive instructions are issued as to the management of the works, rates of pay for assistants and workmen, and other matters. One condition laid down by the State is that in all constructive work eight hours shall constitute a day's work for all labourers and mechanics.

For the use of the staff engaged in the hydrological department a manual ${ }^{2}$ has been issued containing instructions as to the proper method of taking observations and the best form of float and current meters to be used under different conditions, with illustrations of the different kinds of meters in use and the method of using the same from bridge, cable, and boat stations; forms of reports, diagrams of discharge and current observations; with formulæ and tables to be used in computations.

From time to time the reports sent in by the staff as to the results of the various surveys and works going on are issued by the department, some of which, relating to water supply and irrigation, the relation of rainfall to run off and the floods in the Mississippi, have been noticed in Nature of January 7 , July 28 , and November 3 , the last reports, Nos. $89,90,9 \mathrm{I}$, being on the water resources of the Salinas Valley, the geology and water resources of the lower James River Valley, and on the natural features and economic development of drainage areas in Ohio. ${ }^{3}$ 1 "Proceedings of the First Conference of Engineers of the Reclamation
Service, with accompanying Papers." Compiled by F. H. Newell. Water Service, with accompanying Papers." Compiled by F. H. Newell. Water
Supply and Irrigation Paper, No. 93. (Washington : Government Printing Office, r904.)

ב "Hydrographic Manual of the U.S. Geological Survey." Water Supply Papers, No. 94 .

3 "On Destructive Floods in the United States in $x 903$ ": "On the Progress of Stream Measurements for roo3": "Underground Waters in gress of Stream Measurements for 1903": "Underground Waters in United States in 1903 "; "The Underground Waters of Arizona."

"Water Resources of the Salinas Valley, California." Paper No. 89.

"Geology and Water Resources of the Lower James River Valley." Water Supply and Irrigation Paper, No. 9o.

"The Natural Features and Economic Development of the Sandusky, Maumee, Muskingum, and Miami Drainage Areas in Ohio." Water Supply and Irrigation Paper, No. 9x.

"Destructive Floods in the United States in rgo3." By E. C. Murphy Paper No. 96 .

"Report on the Progress of Stream Measurements for the Calendar Year 1903." By J. C. Hayt. Paper No. 97.

"Report on the Progress of Stream Measurements for the Calendar Year Igo3." By J. C. Hayt. Paper No. 98.

"Underground Waters of Southern Louisiana." By G. D. Harris. Paper No. ror.

"Contributions to the Hydrology of Eastern United States." By M. L. Fuller. Paper No. 102.

"The Underground Waters of Gila Valley, Arizona." By W. T. Lee. Paper No. 104. (Washington: Government Printing Office, 1904.) NO, I 834 , VOL. 7 I ] 